\title{
CONF-9.21101--45
}

PNL-SA--2032.9

DE93 005: 37

A DEMONSRATION OF DOSE MODELING AT YUCCA MOUNTAIN<smiles>COC#CCOCCO</smiles>

T. B. Miley

P. W. Eslinger

November 1992

Presented at the

Materials Research Society 16th International Symposium on the Scientific Basis for Nuclear Waste Management November 30 - December 4, $1992^{-}$ Boston, Massachusetts

Prepared for the U. S. Department of Energy under Contract DE-AC06-76RLO 1830

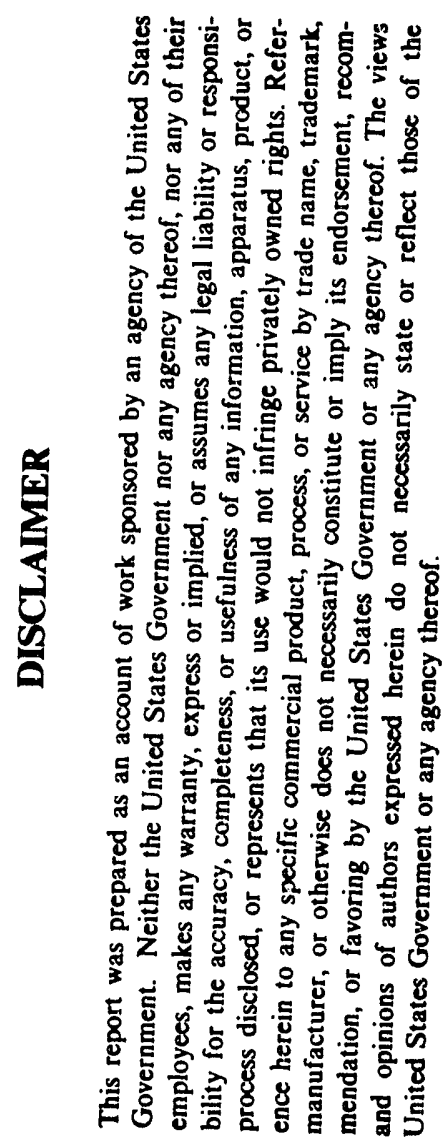

Pacific Northwest Laboratory Richland, Washington 99352 


\section{A DEMONSTRATION OF DOSE MODELING AT YUCCA MOUNTAIN}

TERRI B. MILEY AND PAUL W. ESLINGER

Pacific Northwest Laboratory ${ }^{\text {a }}$, P.O. Box 999, Richland, WA 99352

\section{ABSTRACT}

The U. S. Environmental Protection Agency is currently revising the regulatory guidance for high-level nuclear waste disposal. In its draft form, the guidelines contain dose limits. Since this is likely to be the case in the final regulations, it is essential that the U.S. Department of Energy be prepared to calculate site-specific doses for any potential repository location. This year, Pacific Northwest Laboratory (PNL) has made a first attempt to estimate doses for the potertial geologic repository at Yucca Mountain, Nevada as part of a preliminary total-systems performance assessment.

A set of transport scenarios was defined to assess the cumulative release of radionuclides over 10,000 years under undisturbed and disturbed conditions at Yucca Mountain. Dose estimates were provided for several of the transport scenarios modeled. The exposure scenarios used to estimate dose in this total-systems exercise should not, however, be considered a definitive set of scenarios for determining the risk of the potential repository.

Exposure scenarios were defined for waterborne and surface contamination that result from both undisturbed and disturbed performance of the potential repository. The exposure scenarios used for this analysis were designed for the Hanford Site in Washington. The undisturbed performance scenarios for which exposures were modeled are gas-phase release of ${ }^{14} \mathrm{C}$ to the surface and natural breakdown of the waste containers with waterborne release. The disturbed performance scenario for which doses were estimated is exploratory drilling. Both surface and waterborne contamination were considered for the drilling intrusion scenario.

\section{INTRODUCTION}

Regulatory changes to 40 CFR $191^{1}$ are pending that would impose limits on individual dose for undisturbed conditions, and population doses for both undisturbed and disturbed conditions on a global scale. In light of these changes, it is important to be able to estimate doses for scenarios being proposed at Yucca Mountain. Lengthening the regulatory time period from 1,000 to 10,000 years removes the possibility for the U.S. Department of Energy (DOE) to rely on waste container lifetimes to meet the individual dose limit requirement.

The DOE's Yucca Mountain Site Characterization Project Office has conducted a series of preliminary total-systems performance assessments for the potential geologic repository at Yucca Mountain, Nevada. PNL produced dose estimates for several of the scenarios modeled using both PNL and Sandia National Laboratories (SNL) estimates of radionuclide release to the accessible environment. Table I summarizes the transport scenarios run and associated exposure scenarios.

The scenarios modeled in this total-systems exercise were driven by transport considerations. The exposure scenarios run were designed for the Hanford Site and are not necessarily valid in the arid environment of Yucca Mountain. The presence of a major surface water body at Hanford makes any scenario dependent on irrigation reasonable for consideration. This is not the case at Yucca Mountain.

\footnotetext{
Oaperated by Battelle Memorial Institute for the U.S. Department of Energy under Contract DE-AC06-76RLO 1830.
} 
Table I. Summary of Calculations

\begin{tabular}{|c|c|c|}
\hline \multicolumn{2}{|c|}{ Transport Scenario } & Exposure Scenario \\
\hline \multirow[t]{3}{*}{ Waterborne } & Base Case & DW Only \\
\hline & $\mathrm{HI}^{(\mathrm{a})}$ - Tuff & DW Only \\
\hline & $\mathrm{HI}^{(\mathrm{a})}$ - Carbonate & Farm \\
\hline \multirow[t]{4}{*}{ Surface } & Base Case & Garden \\
\hline & $\mathrm{HI}^{(\mathrm{a})}$ - Driller & Driller \\
\hline & $\mathrm{HI}^{(\mathrm{a})}$ - Post-Drilling & External Only \\
\hline & $\mathrm{HI}^{(\mathrm{a})}$ - Post-Drilling & Garden \\
\hline
\end{tabular}

(a) HI - human intrusion.

\section{TRANSPORT SCENARIOS}

Transport scenarios for which doses were estimated are base-case studies and perturbed-case studies for both waterborne and surface contamination. The waterborne scenarios include the undisturbed breakdown of the waste containers with release to an underground water source, injection of waste into a shallow aquifer from exploratory drilling, and injection of waste into a deep aquifer from exploratory drilling. The surface contamination scenarios are gaseous release of ${ }^{14} \mathrm{C}$ to the surface and exhumation of the contents of a waste container to the surface from exploratory drilling. The nuclides chosen by consensus of the transport modelers were ${ }^{14} \mathrm{C},{ }^{79} \mathrm{Se}$, ${ }^{99} \mathrm{Tc},{ }^{126} \mathrm{Sn},{ }^{129} \mathrm{I},{ }^{135} \mathrm{Cs},{ }^{234} \mathrm{U},{ }^{237} \mathrm{~Np},{ }^{239} \mathrm{Pu}$, and ${ }^{243} \mathrm{Am}$.

\section{EXPOSURE SCENARIOS}

Doses were calculated for a representative individual for a 70-year period. Several exposure scenarios were applied to that individual, depending on the transport scenario considered. The individual was subjected to maximal exposure in terms of his proximity to the site and activities at the site, but ingestion parameters were set at an "average" value, not a maximal value. No attempt was made to establish population doses on either local or global scale.

The exposure scenarios used in these analyses were developed for application at the Hanford Site in the state of Washington. The arid climates of Hanford and Yucca Mountain are similar, but the Hanford Site has a major source of surface water, the Columbia River. The Columbia River makes many irrigation-based exposure scenarios valid at Hanford which are not necessarily valid at Yucca Mountain. However, gathering site-specific data on Yucca Mountain related to exposure was not within the scope of these analyses, and the Hanford exposure scenarios were applied with the preceding caveat.

\section{Waterborne Exposure Scenarios}

There are two exposure scenarios used for waterborne transport modeling. The first is an individual residing and receiving his food supply from a small farm, and the second is an individual receiving only drinking water from the contaminated source. In both scenarios, the receptor well is assumed to be located $5 \mathrm{~km}$ downgradient from the repository at the boundary of the controlled zone. 
A farm scenario is used when there is a significant source of groundwater. In this scenario, the farmer inhabits a $20,000 \mathrm{~m}^{2}$ farm on which irrigation water is used to grow edible plants and water livestock. The individual consumes 2 liters of contaminated water per day from one of the two aquifers considered in these simulations--the shallow tuff aquifer or the deep carbonate aquifer. The farm supports $100 \%$ of the individual's leafy vegetable $(15 \mathrm{~kg} / \mathrm{yr})$, other vegetable $(276 \mathrm{~kg} / \mathrm{yr})$, meat $(80 \mathrm{~kg} / \mathrm{yr})$, eggs $(20 \mathrm{~kg} / \mathrm{yr})$, poultry $(8.5 \mathrm{~kg} / \mathrm{yr})$, and milk $(230 \mathrm{~L} / \mathrm{yr})$ intake. With the exception of meat, all values for the consumption rates are taken from the average individual column of Table F.6 of the Hanford Defense Waste Environmental Impact Statement. $^{2}$ The value used for meat has been increased by $10 \mathrm{~kg} / \mathrm{yr}$ to estimate consumption of meats other than beef and pork. If there is not enough water to support a farm, the individual is exposed to 2 liters per day of drinking water only.

\section{Surface Contamination Scenarios}

There are three scenarios for exposure to surface contamination. For all surface contamination exposure, the individual is assumed to be located directly above the repository. In the exploratory drilling intrusion transport scenario, there is a driller working at the site who is exposed to inhalation of drilling dust for 1 hour and to external contact with contaminants for 40 hours. The second exposure scenario for surface contamination is a garden exposure scenario over a 70 -year period. The gardener resides on contaminated soil and has a $2,500 \mathrm{~m}^{2}$ garden in which he produces fruit and vegetables. Because the gardener does not entirely support his fruit and vegetable intake from his home garden, the consumption rate estimates used for this scenario are $25 \%$ of the maximum individual numbers from Table F. $6^{2}$ cited above. These rates are $7.4 \mathrm{~kg} / \mathrm{yr}$ of leafy vegetables and $160 \mathrm{~kg} / \mathrm{yr}$ of other vegetables. No animal products are produced on the contaminated homestead. A third scenario is included to model only external exposure to the contaminated soil. This scenario can be used when there is not sufficient water to use the garden scenario or when several scenarios are being used together and "double counting" could be a problem.

\section{DOSE MODEL DESCRIPTION}

The exposure scenarios chosen for the dose calculations by PNL necessitated using two codes--SUMO and GENII. ${ }^{3}$ SUMO's dose module was used to evaluate doses from waterborne scenarios. GENII was used to evaluate doses that are due to surface contamination. Both codes calculate a dose increment for a 70-year period, which represents one human lifetime. The GENII code calculates dose for a single 70-year period. The dose module of SUMO can calculate doses for sources of any duration. Long-duration doses are calculated as the sum of consecutive 70-year doses. Both SUMO and GENII calculate internal dosimetry to a number of target organs. The effective dose is the sum of organ doses multiplied by organ weighting factors for the six whole body organs defined in ICRP $26^{4}$ and the five remaining organs receiving the highest doses. Both models also calculate external doses resulting from submersion in contaminated air and dermal contact with contaminated soil. The doses reported here are lifetime effective dose equivalents, which are the sum of the organ-weighted internal dose and the external doses.

\section{RESULTS}

Only a few of the calculations performed for these analyses could be presented. The runs selected involved the greatest number of the possible exposure pathways. For 
waterborne transport, results will be presented for one PNL-modeled run and for one SNL-modeled run. Surface contamination transport scenario results are presented for one PNL-modeled and one SNL-modeled ${ }^{14} \mathrm{C}$ gas-phase release run and for a set of PNL-modeled stochastic runs with all three surface exposure scenarios applied.

\section{Waterborne Results}

The aquifer flow parameters establish the volume of water in which contaminants are diluted. The aquifer flow parameters used in the transport modeling are presented in Table II. For both of the waterborne scenario runs presented, the aquifer modeled is the deep carbonate aquifer and the exposure scenario is the farmer.

Table II. Aquifer Flow Parameters

\begin{tabular}{lrrrrr} 
& \multicolumn{2}{c}{ Tuff Aquifer } & & \multicolumn{2}{c}{ Carbonate Aquifer } \\
\cline { 2 - 3 } & \multicolumn{1}{c}{ PNL } & SNL & & PNL & SNL \\
\cline { 2 - 3 } & $7.7 E-3$ & 4.07 & & 60.7 & 230 \\
Pore Velocity (m/yr) & 0.24 & 0.175 & & 0.05 & 0.05 \\
Porosity & $1.85 E-3$ & 0.71 & & 3.04 & 11.5
\end{tabular}

The first example presented gives dose estimates for PNL-modeled drilling intrusion into the deep carbonate aquifer. Transport through the hydrologic media was modeled by the transport module of SUMO. Time-release rate pairs were provided to the dose module of SUMO. The simulation was run for 10,000 years. The drilling event occurred 1,000 years after repository closure. PNL ran ten stochastic simulations, a minimum groundwater flow rate run, and a maximum groundwater flow rate run. The maximum flow rate run is presented here.

The maximum dose occurred in the 70 -year period beginning in year 4620 . The individual residing in this period received a dose of $3.6 \mathrm{mrem} / \mathrm{yr}$. The nuclide ${ }^{237} \mathrm{~Np}$ contributed $99 \%$ of the dose, with the remaining $1 \%$ of dose contributed in trace amounts from other nuclides. The organs that received the highest doses are the bone surface, the red marrow, and the liver. The nuclide by pathway dose table provided by SUMO showed the terrestrial ingestion pathway was responsible for $98 \%$ of the dose. Further runs were made that revealed that $92 \%$ of the $3.6 \mathrm{mrem} / \mathrm{yr}$ dose was through the vegetable ingestion pathway. This pathway had a consumption rate of $276 \mathrm{~kg} / \mathrm{yr}$, a yield of $4 \mathrm{~kg} / \mathrm{m}^{2}$, and a growing period of 90 days.

The second example is a SNL-modeled drilling intrusion into the deep carbonate aquifer. The maximum dose for this run occurred in the 70 -yr period beginning in year 700. The individual residing in this time period received a dose of $2.1 \mathrm{mrem} / \mathrm{yr}$. The nuclide ${ }^{237} \mathrm{~Np}$ contributed $98 \%$ of the dose, with the remaining $2 \%$ of dose contributed in trace amounts from other nuclides. As in the PNL case, the organs that received the highest doses are the bone surface, the red marrow, and the liver. The results by organ for both the SNL and PNL examples given here are summarized in Table III.

Table III. ${ }^{237} \mathrm{~Np}$ Dose (mrem/yr) by Organ for Drilling Intrusion Runs

\begin{tabular}{|c|c|c|c|}
\hline & Bone Surface & $\underline{\text { Red Marrow }}$ & Liver \\
\hline PNL & $2.4 \mathrm{E}+0$ & $8.3 E-1$ & $2.2 \mathrm{E}-1$ \\
\hline SNL & $1.4 \mathrm{E}+0$ & 4.7E-1 & $1.3 \mathrm{E}-1$ \\
\hline
\end{tabular}


The differences in the dose results for PNL and SNL are due to differences in the source term modeling and the difference in water flux presented in Table II above. The exposure scenario for both PNL and SNL drilling intrusion into the deep carbonate aquifer is the farm scenario. Organ weighting factors have been applied to the doses presented in Table III. These are 0.03 for the bone surface, 0.12 for the red marrow, and 0.06 for the liver.

\section{Surface Contamination Results}

The ${ }^{14} \mathrm{C}$ gas-phase releases to the surface were calculated for both PNL and SNL. A garden exposure scenario was used for this transport scenario. The exposure scenario requires computation of an air concentration $\left(\mathrm{Ci} / \mathrm{m}^{3}\right)$ for ${ }^{14} \mathrm{C}$. The calculation requires site-specific parameters which were obtained from the Site Characterization Plan for Yucca Mountain ${ }^{5}$. The average annual wind speed at Yucca Mountain is 3.3 $\mathrm{m} / \mathrm{s}$, and the surface area of the repository is $5.67 \mathrm{E} 6 \mathrm{~m}^{2}$. A plane is defined with length equal to the square root of the repository area and a height equal to an assumed $10-\mathrm{m}$ above ground level mixing depth. A total air volume $\left(\mathrm{m}^{3} / \mathrm{yr}\right)$ equal to the product of the area of the plane described above and the average annual wind speed was divided into the source $(\mathrm{Ci} / \mathrm{yr})$ to obtain the average air concentration. The maximum results received over the 10,000-year period are given in Table IV.

\section{Table IV. ${ }^{14} \mathrm{C}$ Gas-Phase Release Summary}

$\begin{array}{lccccc} & \begin{array}{c}\text { Time } \\ (\mathrm{yr})\end{array} & \begin{array}{c}\text { Source } \\ (\mathrm{Ci} / \mathrm{yr})\end{array} & \begin{array}{c}\text { Dose } \\ (\mathrm{mrem} / \mathrm{yr})\end{array} & \begin{array}{c}\text { Maximum } \\ \text { Organ }\end{array} & \begin{array}{c}\text { Maximum } \\ \text { Pathway }\end{array} \\ \mathrm{PNL} & 10000 & 1.00 \mathrm{E}-2 & 8.5 \mathrm{E}-4 & \text { Red Marrow } & \text { Ingestion } \\ \mathrm{SNL} & 3550 & 1.42 \mathrm{E}+0 & 1.2 \mathrm{E}-1 & \text { Red Marrow } & \text { Ingestion }\end{array}$

The differences in the dose for this scenario are due strictly to the difference in source term release models used by the individual laboratories.

The other surface contamination transport scenario considered was human intrusion by exploratory drilling. Only PNL releases were modeled for this scenario. Three exposure scenarios were modeled for this release: 1) a driller, 2) a post-drilling gardener, and 3) a post-drilling dweller exposed only externally. The entire contents of one waste container were exhumed to the surface. The results for this scenario are given in Table $\mathrm{V}$.

Table V. PNL Direct-Hit Spent Fuel Drilling Intrusion Summary

\begin{tabular}{|c|c|c|c|}
\hline Run No. & $\begin{array}{c}\text { Driller Dose } \\
\text { (mrem) }\end{array}$ & $\begin{array}{l}\text { Post-Drilling } \\
\text { Gardener Dose } \\
\text { (mrem/yr) }\end{array}$ & $\begin{array}{l}\text { Post-Drilling } \\
\text { External Dose } \\
\text { (mrem/yr) }\end{array}$ \\
\hline 2 & $1.1 \mathrm{E}+4$ & $2.71 \mathrm{E}+5$ & $2.86 E+4$ \\
\hline 3 & $1.4 E+4$ & $2.57 \mathrm{E}+5$ & $3.14 E+4$ \\
\hline 4 & $3.7 E+3$ & $8.29 E+4$ & $9.14 E+3$ \\
\hline 5 & $1.2 \mathrm{E}+4$ & $2.57 \mathrm{E}+5$ & $3.00 E+4$ \\
\hline 6 & $5.6 \mathrm{E}+3$ & $1.29 E+5$ & $1.40 E+4$ \\
\hline 7 & $4.6 E+3$ & $7.71 E+4$ & $1.04 E+4$ \\
\hline 8 & $3.8 \mathrm{E}+3$ & $6.86 \mathrm{E}+4$ & $8.86 E+4$ \\
\hline 9 & $7.6 \mathrm{E}+3$ & $1.20 E+5$ & $1.71 \mathrm{E}+4$ \\
\hline 10 & $3.7 E+3$ & $9.71 E+4$ & $8.80 E+3$ \\
\hline
\end{tabular}


The dose to an individual from the human intrusion scenario is very high, particularly for the post-drilling dweller with a garden. The current proposed revision to 40 CFR 191 does not impose a dose limit for an individual under disturbed conditions; rather the exposed individual contributes to the population dose limit. This underlines the importance of defining appropriate exposure scenarios to use in dose modeling for the potential repository at Yucca Mountain. These high doses will occur only if it is feasible for an individual to be residing and supporting a garden directly above or adjacent to the potential repository.

\section{SUMMARY AND CONCLUSIONS}

A major issue in the revision of 40 CFR 191 is consideration of a dose-based limit. If a dose-based limit is adopted, the DOE's Office of Civilian Radioactive Waste Management must have a dose modeling capability in place. Several studies are being pursued as defined in the Yucca Mountain SCP which will provide information necessary for modeling dose. A comprehensive set of scenarios describing release to the accessible environment must be determined. Exposure scenarios appropriate to these transport scenarios will then be defined. Of particular concern is the determination whether a significant source of groundwater exists at Yucca Mountain. Also, the regional groundwater flow system must be defined well enough to model the effect on the system of pumping large quantities of water from the aquifers. The irrigation-based exposure scenarios depend on this information.

Estimates have been made in these simulations for both disturbed and undisturbed performance. Further work in the dose modeling area will have to be done to address intrusion scenarios such as tectonics and volcanism, as they are expected to be included on the final scenario list. The simulations applied to surface contamination ignore any type of controlled zone around the repository. The waterborne scenarios provide for releases at the currently-defined $5 \mathrm{~km}$ boundary. Exposure scenarios used in these analyses were defined for the Hanford Site in Washington. Site-specific parameters will have to be obtained to customize the dose modeling for Yucca Mountain.

\section{REFERENCES}

1. U. S. ENVIRONMENTAL PROTECTION AGENCY, "Environmental Standards for the Management and Disposal of Spent Fuel, High-Level and Transuranic Radioactive Wastes, Final Rule," 40 CFR Part 191, Federal Register, Vol. 50, pp. 38006-38089 (1985).

2. "FINAL ENVIRONMENTAL IMPACT STATEMENT: Disposal of Hanford Defense HighLevel, Transuranic and Tank Wastes, Hanford Site, Richland, Washington," DOE/EIS-0113, U. S. Department of Energy (1987).

3. B. A. NAPIER, R. A. PELOQUIN, D. L. STRENGE, and J. V. RAMSDELL, "Hanford Environmental Dosimetry Upgrade Project. GENII - The Hanford Environmental Radiation Dosimetry Software System. Volume 1: Conceptual Representation," PNL-6584 Vol. 1, 2, and 3, Pacific Northwest Laboratory (1988).

4. International Commission on Radiological Protection (ICRP), "Recommendations of the International Commission on Radiological Protection." ICRP Publication 26, Pergamon Press, New York (1977).

5. "SITE CHARACTERIZATION PLAN: Yucca Mountain Site, Nevada Research and Development Area, Nevada," DOE/RW-0199, U. S. Department of Energy (1988). 

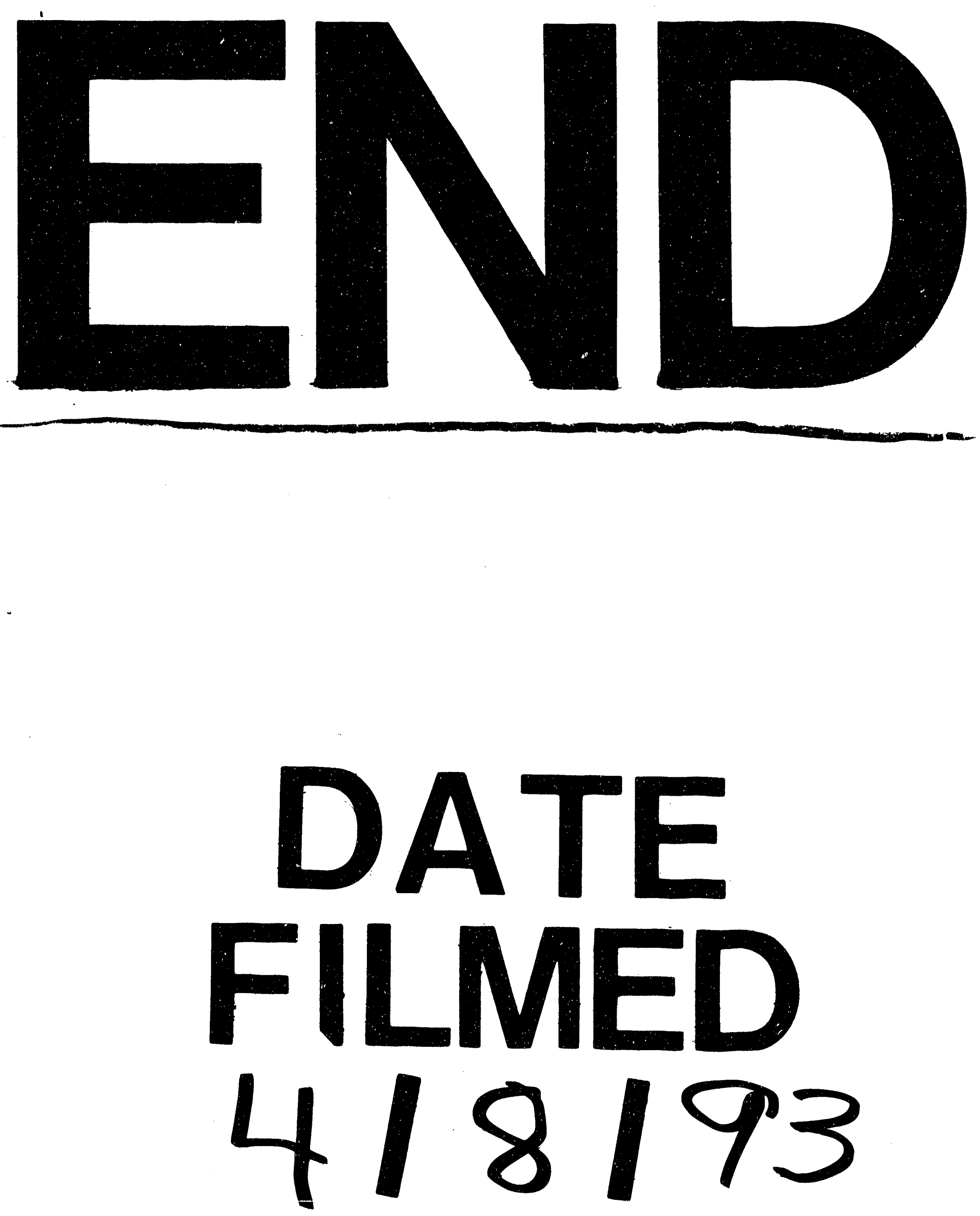
